\title{
Biodegradation of Naphthalene by Staphylococcus pasteuri RD2 Isolated from Oil Contaminated Soil
}

\author{
Ruby Doley and Manoj Barthakur*
}

\author{
Department of Botany, B.Borooah College, Guwahati, Assam, India \\ *Corresponding author
}

\begin{tabular}{|c|c|}
\hline & A B S T R A C T \\
\hline $\begin{array}{l}\text { Naphthalene, } \\
\text { Staphylococcus } \\
\text { pasteuri, } \\
\text { Biodegradation, UV- } \\
\text { Spectroscopy, FT-IR, } \\
\text { GC-MS. }\end{array}$ & \multirow{3}{*}{$\begin{array}{l}\text { Naphthalene is a polycyclic aromatic hydrocarbon (PAHs) consisting of a pair of benzene } \\
\text { ring and is considered as priority pollutants among } 16 \text { PAHs by US Environmental } \\
\text { Protection Agency (USEPA, 1994, 2004) is highly toxic, mutagenic and carcinogenic. Due } \\
\text { to its lipophilic property it enters the ecosystem and polluted the environment. A Bacterial } \\
\text { strain isolated from oil polluted site of Guwahati Oil Refinery was identified as } \\
\text { Staphylococcus pasteuri RD2, based on 16SrDNA sequences and phylogenetic analysis. } \\
\text { The bacterial strain was able to degrade naphthalene in culture broth in to a number of its } \\
\text { transformation products were monitored through FT-IR and GC-MS. Detection of } \\
\text { degraded products in the culture broth such as1-cyclohexane-1-carboxylic, 1,2- } \\
\text { cyclohexanedicarboxyldehyde, ethylhexyl salicylate, phthalic acid, acetic acid, oxalic acid, } \\
\text { propanoic acid, 2-ethyl hexyl salicyclic acid and 1,2-cyclohexanedicarboxyldehyde } \\
\text { suggested the degradation of naphthalene by bacterial strain Staphylococcus pasteuri RD2. }\end{array}$} \\
\hline Article Info & \\
\hline $\begin{array}{l}\text { Accepted: } \\
\text { 12 October } 2017 \\
\text { Available Online: } \\
10 \text { December } 2017\end{array}$ & \\
\hline
\end{tabular}

\section{Introduction}

Hydrocarbons are a group of organic compounds composed exclusively of carbon and hydrogen and are either monocyclic- or polycyclic aromatic in structure. Monocyclic aromatic hydrocarbons like benzene, ethylbenzene, toluene and xylene (BTEX) having a single benzene ring, are commonly found in gasoline and are highly volatile substances (Coates et al., 2002). Polycyclic aromatic hydrocarbons (PAHs) contain two or more benzene rings and are relatively less aqueous soluble than monocyclic aromatic hydrocarbons. Aromatic hydrocarbons are considered as highly toxic, and carcinogenic to human health. These pollutants are released from combustion of fossil fuels and hydrocarbons that enter the ecosystem due to their lipophilic property and polluted the environment. The aromatic hydrocarbons like Naphthalene, Benzene, toluene, ethylbenzene, and xylene are commonly found in crude petroleum and petroleum products are considered as one of the major causes of environmental pollution (Farhadian et al., 2008).

Among the PAHs naphthalene is the simplest one and has been extensively used as a model for biodegradation study. Biodegradation of polycyclic aromatic compounds by aerobic and anaerobic microorganisms has been extensively studied and the biochemical degradation pathways have been elucidated by different groups of authors (Mahajan et al., 
1994, Annweiler et al., 2002; Zhang and Young, 1997, Rainer et al., 2004, Meckenstock et al., 2004). Naphthalene consists of a fused pair of benzene rings with chemical formula $\mathrm{C}_{10} \mathrm{H}_{8}$. It is a white, volatile, crystalline solid with a characteristic strong odour which is detectable at concentration as low as 0.08 ppm by mass. Main source of naphthalene is coal tar and petroleum distillation. Naphthalene is one of the 16 PAHs classified as priority pollutant by US Environmental Protection Agency (USEPA, 1994, 2004). Naphthalene is toxigenic, mutagenic and carcinogenic which is among the most prevalent pollutants in the environment and as such for assuring human health, removal of naphthalene from the environment is very much important.

Microorganisms play a vital role in cleaning up the environment by degrading the environmental pollutants. Disintegration of the pollutants by bacteria is called biodegradation which is one of the effective ways in the context of removing environmental pollutants. Bioremediation is generally considered a safe and less expensive method for removal of hazardous contaminants and production of non-toxic biproducts (Ward et al., 2003). Recently many authors have reported degradation of naphthalene using different microbial agents with several pathways and degradation metabolites. Mittal and Singh (2009) measured the microbial degradation value of Naphthalene through Gas Chromatography. Chen Lin et al., (2010) worked on biodegradation of naphthalene by strain Bacillus fusiformis (BFN). Othman et al., (2010) performed degradation of polycyclic aromatic hydrocarbon using Micrococcus sp. Rhodococus sp. Corynebacterium sp. and Padiococcus sp. isolated from municipal sludge. Kafilzadeh et al., (2011) reported degradation of naphthalene by 5 bacterial species belonging to Staphylococcus sp.
Corynebacterium sp. Pseudomonas sp. Bacillus sp. and Micrococcus sp. Pawar et al., (2013) characterized gram positive and gram negative bacteria belonging to genus Micrococcus sp. Bacillus sp. Staphylococcus sp. and Pseudomonas sp. isolated from marine and petroleum soil samples which showed degradation of naphthalene. B. Prajapati et al., (2016) reported degradation of Naphthalene by Bacillus subtilis isolated from petroleum contaminated soil. Here, in our study we report degradation of naphthalene by bacterial strain identified as Staphylococcus pasteuri RD2 isolated from Guwahati Oil refinery able to utilize naphthalene as a sole source of carbon and energy. The degradation metabolites of naphthalene in bacterial culture were identified through FTIR and GC-MS spectroscopy.

\section{Materials and Methods}

\section{Sample collection}

Oil contaminated soil samples were collected in a sterilized polythene bag from Guwahati oil refinery, Assam, India. The soil sample was allowed to dry for two days.

\section{Isolation, characterization and identification of microorganisms}

Stock solution was prepared by mixing $1 \mathrm{gm}$ of the oil contaminated soil sample in $100 \mathrm{ml}$ of sterilized distilled water and then subjected to serial dilution from $10^{-2}$ to $10^{-9}$. Plating was done in Nutrient agar media with $\mathrm{pH} 7.3$ and then incubated at $37^{\circ} \mathrm{C}$. After 7 days of incubation period, different colonies were isolated which were again transferred in nutrient agar plates supplemented with $100 \mathrm{mg}$ naphthalene with $\mathrm{pH} 7.3$ for preliminary screening to isolate potent strain with naphthalene degrading ability. It was again incubated at $37^{\circ} \mathrm{C}$ for another 7 days. 
The isolated strain was characterized through different biochemical tests according to Cappuccino and Sherman (1983) and Bergy's manual of systematic bacteriology (1984).

For identification of the isolated strain, DNA was isolated from the culture. Its quality was evaluated on $1.0 \%$ Agarose Gel. A single band of high-molecular weight DNA was observed. Fragment of 16S rDNA gene was amplified by $27 \mathrm{~F}$ and $1492 \mathrm{R}$ primers. A single discrete PCR amplicon band of 1500 base pairs was observed when resolved on Agarose gel. The PCR amplicon was purified to remove contaminants. Forward and reverse DNA sequencing reaction of PCR amplicon was carried out with forward primer and reverse primers using BDT v3.1 Cycle sequencing kit on ABI 3730xl Genetic Analyzer. Consensus sequence of 16S rDNA gene was generated from forward and reverse sequence data using aligner software. The $16 \mathrm{~S}$ rDNA gene sequence was used to carry out BLAST with the database of NCBI genebank database. Based on maximum identity score first ten sequences were selected and aligned using multiple alignment software programs. Clustal W. Distance matrix was generated and the phylogenetic tree was constructed using MEGA 7. Sequencing of the $16 \mathrm{~S}$ rDNA was carried out by Eurofin Genomic, Bangalore, India.

The morphology of the isolate was observed by viewing under Scanning Electron microscope (SEM).

\section{Growth determination of the isolate}

To determine the growth of the isolate, different factors like temperature, $\mathrm{pH}$, salinity and naphthalene concentration was taken under consideration. Experiments were performed to examine the effect of these factors on the growth of the isolate and degradation of naphthalene. The isolate was inoculated in nutrient broth and incubated at different temperatures of $25,27,30,32,35$, 37 and $40^{\circ} \mathrm{C}$. $\mathrm{pH}$ of the medium for the experiment was adjusted to $6,6.3,6.5,6.8,7$, 7.3, 7.5 and 8 using $1 \mathrm{M} \mathrm{HCl}$ and $1 \mathrm{M} \mathrm{NaOH}$. Salinity used was $0,1,4,7,10,12$ and 15/L. $1000 \mathrm{ppm}$ of stock solution of naphthalene dissolved in $\mathrm{n}$-hexane was prepared and from it $60 \mathrm{ppm}, 80 \mathrm{ppm}, 100 \mathrm{ppm}, 150 \mathrm{ppm}$ and $200 \mathrm{ppm}$ naphthalene concentration was used for the experiment.

\section{Naphthalene degradation experiment}

For study of bacterial growth and biodegradation of naphthalene, $1 \mathrm{ml}$ of bacterial suspension inoculated in each of the two $250 \mathrm{ml}$ conical flask, containing $100 \mathrm{ml}$ of nutrient broth supplemented with $60 \mathrm{ppm}$ naphthalene and incubated at $37^{\circ} \mathrm{C}$.

Bacterial growth and naphthalene degradation were monitored periodically at an interval of $24 \mathrm{hrs}$ in UV-Vis spectrophotometer at $600 \mathrm{~nm}$ and $310 \mathrm{~nm}$ respectively. Culture broth supplemented with naphthalene without inoculation of naphthalene was treated as control.

\section{FTIR and GC analysis for naphthalene degradation}

After 7 days of incubation, culture broths containing $60 \mathrm{ppm}$ naphthalene were centrifuged separately at $15000 \mathrm{rpm}$ for 15 minutes. The supernatant were extracted twice in $25 \mathrm{ml} \mathrm{n}$-hexane and filtered through Whatman No.42 filter paper. The filtrate was was dry under vacuum and used for FT-IR and G-C-MS analysis. For FT-IR analysis, a small amount of $\mathrm{KBr}$ was mixed with the dried sample and pellets were made to record the FT-IR spectra of the intermediate metabolites. $60 \mathrm{ppm}$ of naphthalene without inoculation of bacteria was taken as a control in ATR mode for FTIR analysis. 
For GC-MS analysis, dried sample was dissolved in $4 \mathrm{ml} \mathrm{n}$-hexane and transferred in a $5 \mathrm{ml}$ glass vile and then taken for GC-MS analysis (Fig. 6).

\section{Results and Discussion}

\section{Isolation of the bacteria}

A total number of 13 different colonies were isolated from the oil contaminated soil sample, labeled as R1 to R13. Among this only RD2 was recorded as having optimum growth in culture broth supplemented with 40 ppm, and 60 ppm naphthalene. Thus, RD3 was considered for identification and further experiments for naphthalene degradation in this study.

\section{Characterization of isolated Naphthalene degrading strain}

The biochemical and morphological study revealed that the bacterial strain RD2 was Gram positive, spherical and non-motile. It showed positive Catalase, Citrate and Urease test and was able to ferment Glucose, Lactose, Sucrose and Dextrose. It showed negative test for Methyl Red, Vogues Proskeur, Oxidase, Coagulase, Casein and Starch hydrolysis, Nitrate Reduction and Gelatin liquefication (Table 1).

\section{Bacterial identification by $16 \mathrm{~S}$ rDNA analysis}

Amplification of the fragment of $16 \mathrm{~S}$ rDNA was done by $27 \mathrm{~F}$ and $1429 \mathrm{R}$ primers which resulted in the production of 15000 base pairs (Fig. 1a). From forward and reverse sequence data consensus sequence of $16 \mathrm{~S}$ rDNA gene was generated which was used to carry out BLAST with the NCBI genebank database. First ten sequences were selected based on maximum identity score and aligned using multiple alignment software programs and the phylogenetic tree was constructed using MEGA 7 (Fig. 1b). From the analysis, the isolated strain has been identified as Staphylococcus pasteuri with $100 \%$ identity.

\section{SEM studies}

SEM studies revealed the topography and surface structure of the bacteria, Staphylococcus pasteuri RD2 (Fig. 2) from which the spherical structure of the bacteria was evident.

Factors affecting the growth of naphthalene degrading bacteria

To determine the growth of bacteria, it was incubated at different temperatures ranging from $25,27,30,32,35,37,40$ and $45^{\circ} \mathrm{C}$. Within $24 \mathrm{hrs}$ of incubation the bacteria shows maximum growth at $37^{\circ} \mathrm{C}$ but after $40^{\circ} \mathrm{C}$ the growth of the bacteria decreases due to reduction in metabolic activity which shows that $37^{\circ} \mathrm{C}$ is more suitable for the growth of bacteria (Fig. 3a).

The $\mathrm{pH}$ of the growth of bacteria showed more effective on 7.3. With increase or decrease of $\mathrm{pH}$ greatly affects the growth of bacteria (Fig. 3b).

The optimum salinity for the growth of bacteria ranges from 0 to $4 \mathrm{mg} / \mathrm{L}$ of $\mathrm{NaCl}$. With increase in salinity above 4, metabolic activity of the bacteria greatly reduces (Fig. $3 c)$.

The effect of naphthalene concentration on the growth of bacteria showed that up to 80 ppm naphthalene, bacteria shows increase in growth (Fig. 3d) which suggests the naphthalene degradation and further increase in naphthalene concentration resulted in decrease of bacterial growth. Thus, $40 \mathrm{ppm}$ and $60 \mathrm{ppm}$ naphthalene concentration was considered for further experiment. 
Table.1 Biochemical characteristics of naphthalene degrading strain

\begin{tabular}{|l|l|}
\hline Biochemical test & Results \\
\hline Catalase test & Positive \\
\hline Citrate utilization test & Positive \\
\hline Urease test & Positive \\
\hline Glucose fermentation test & Positive \\
\hline Lactose fermentation test & Positive \\
\hline Sucrose fermentation test & Positive \\
\hline Dextrose fermentation test & Positive \\
\hline Methyl Red test & Negative \\
\hline Vogues Proskeur test & Negative \\
\hline Oxidase test & Negative \\
\hline Coagulase test & Negative \\
\hline Casein hydrolysis test & Negative \\
\hline Starch hydrolysis test & Negative \\
\hline Nitrate reduction test & Negative \\
\hline Gelatin liquefication test & Negative \\
\hline
\end{tabular}

Fig.1 (a) gDNA 16S PCR amplicon ladder specification
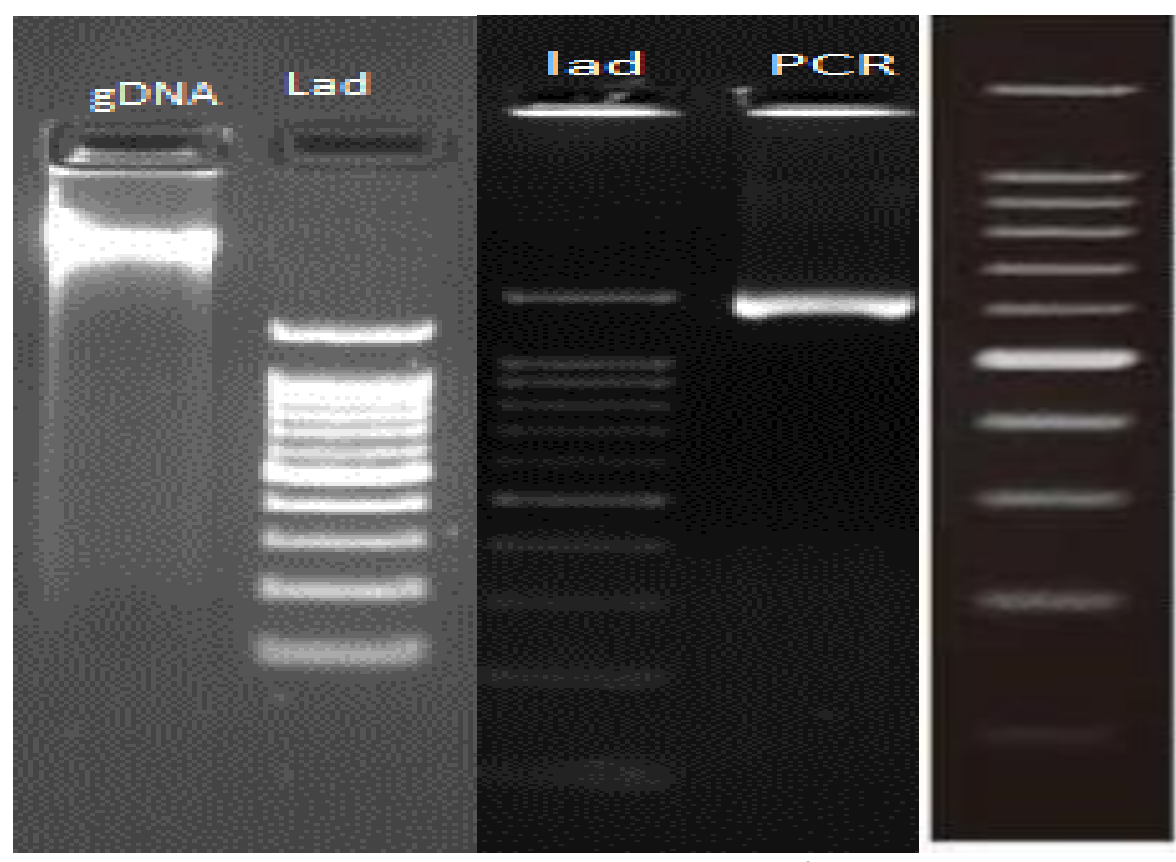
Fig.1 (b) Phylogenetic tree of Staphylococcus pasteuri strain labeled as RD2

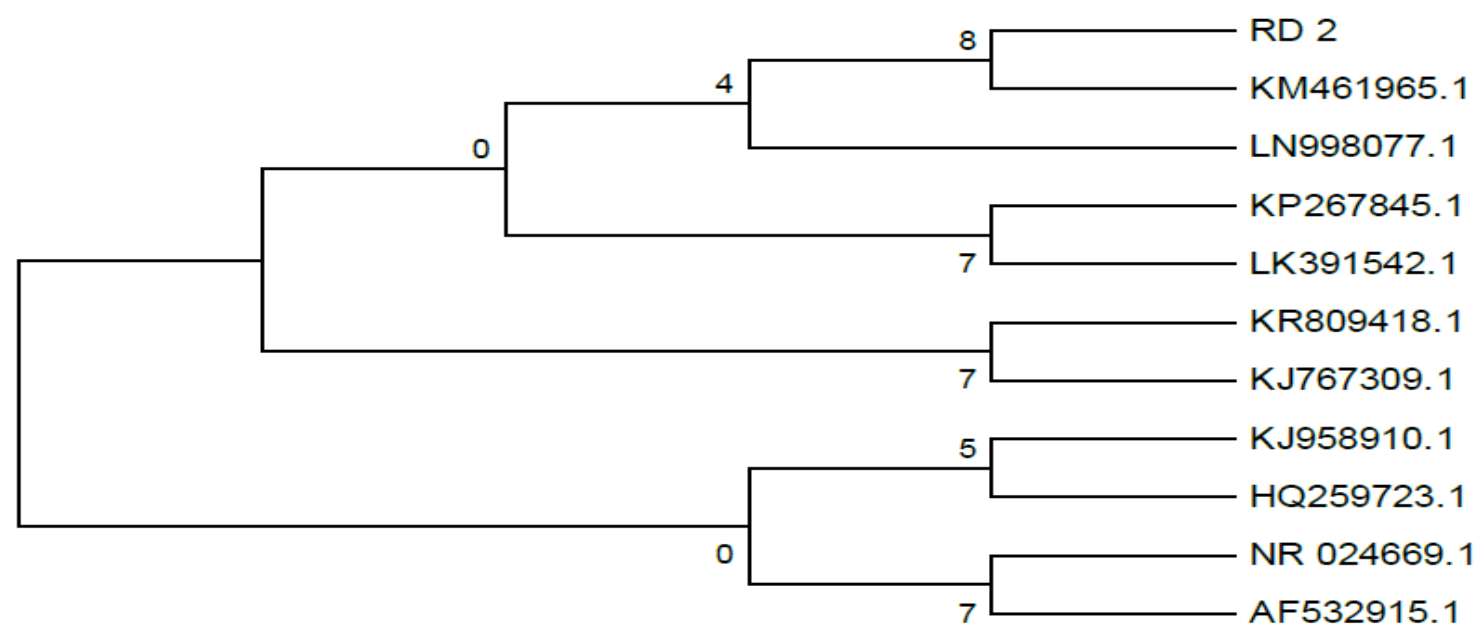

Fig.2 (a) and 2(b) SEM images of Staphylococcus pasteuri in colonies and chains

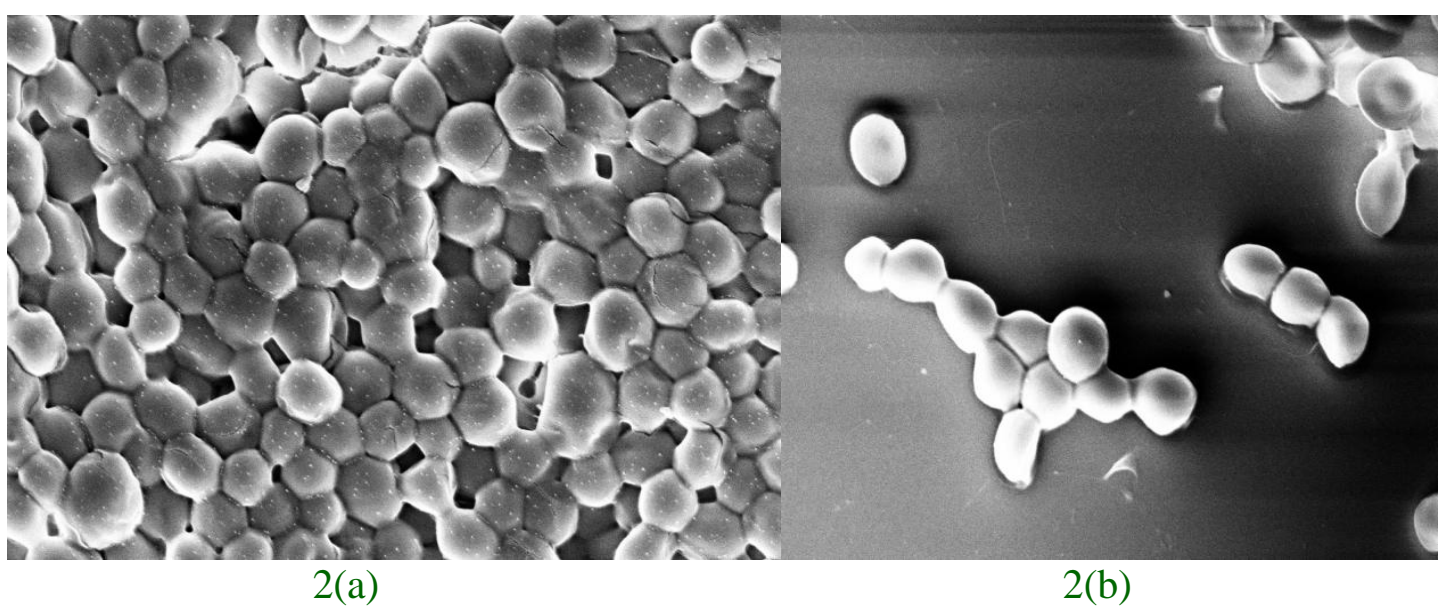

Fig.3 (a) Effect of temperature on bacterial growth; (b) Effect of pH on bacterial growth

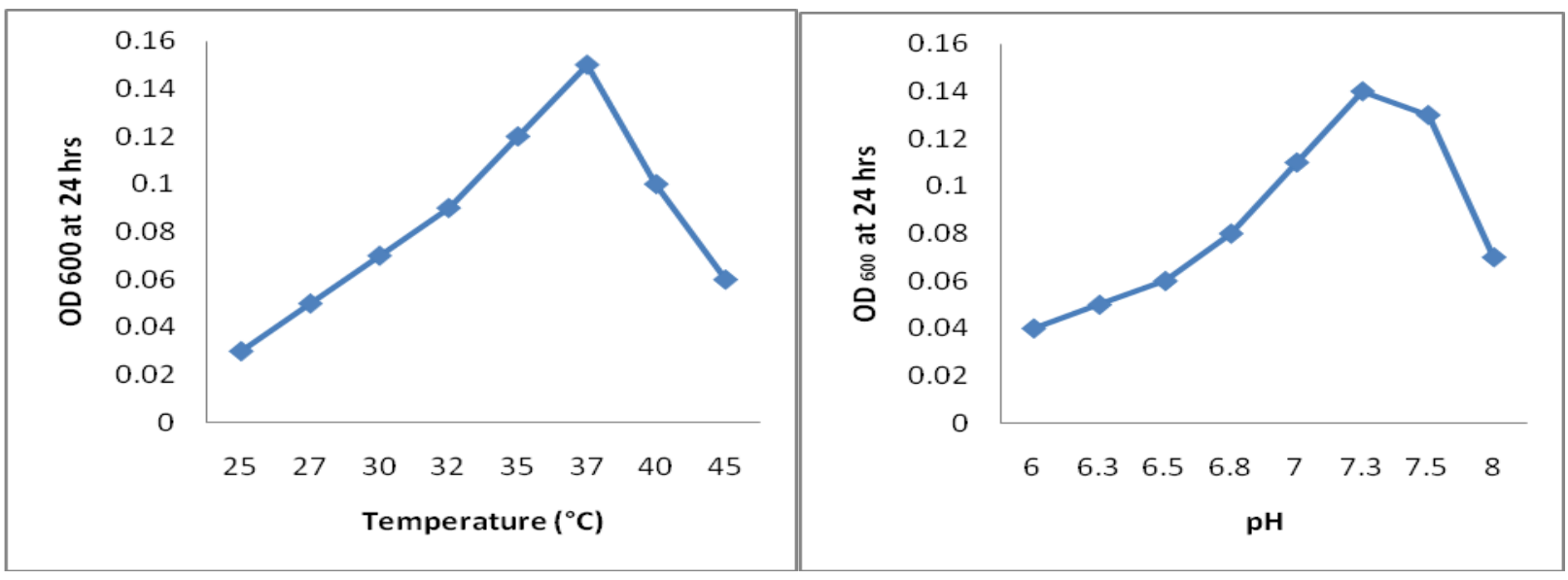


Fig.3 (c) Effect of salinity on bacterial growth; (d) Effect of different concentration of naphthalene on growth

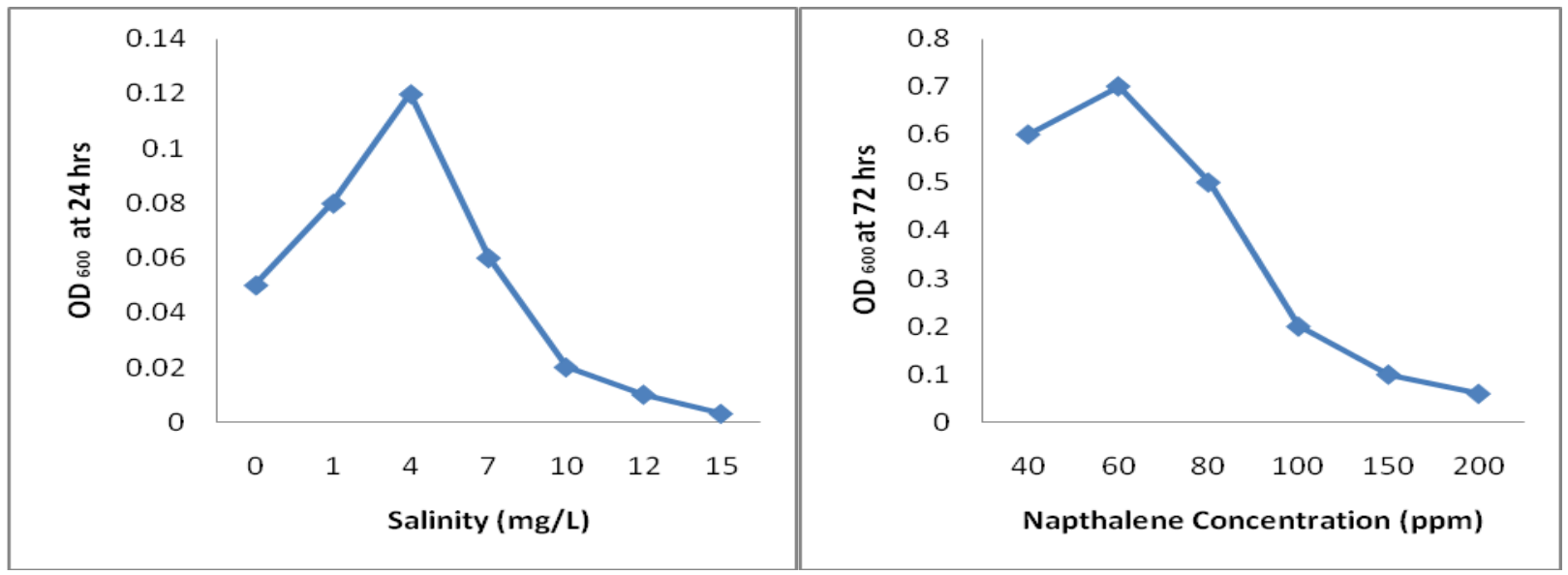

Fig.4 Growth (a) of Staphylococcus pasteuri and naphthalene degradation (b) in 60 ppm naphthalene broth

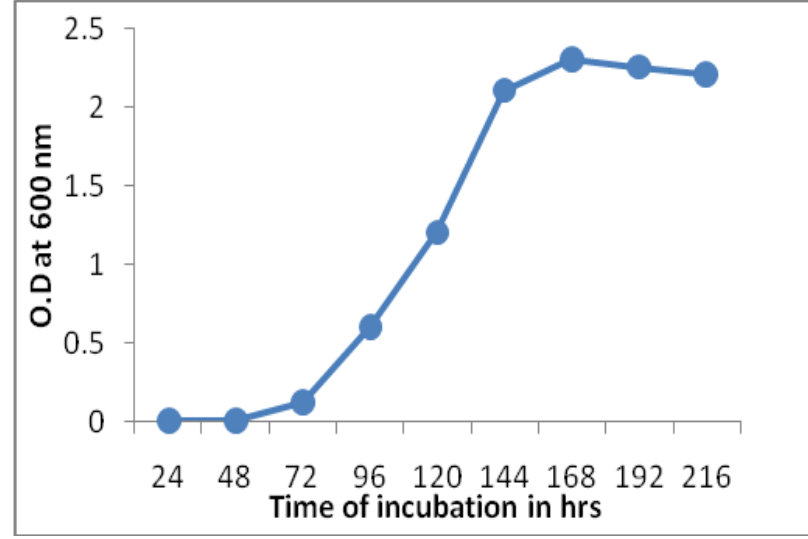

4(a)

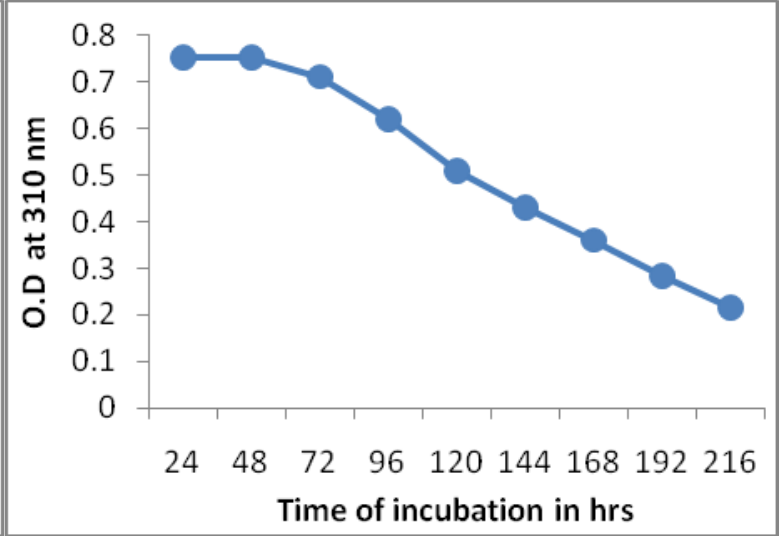

4(b)

Fig.5 (a) FT-IR spectra of 60ppm naphthalene dissolved in hexane (control) taken in ATR mode

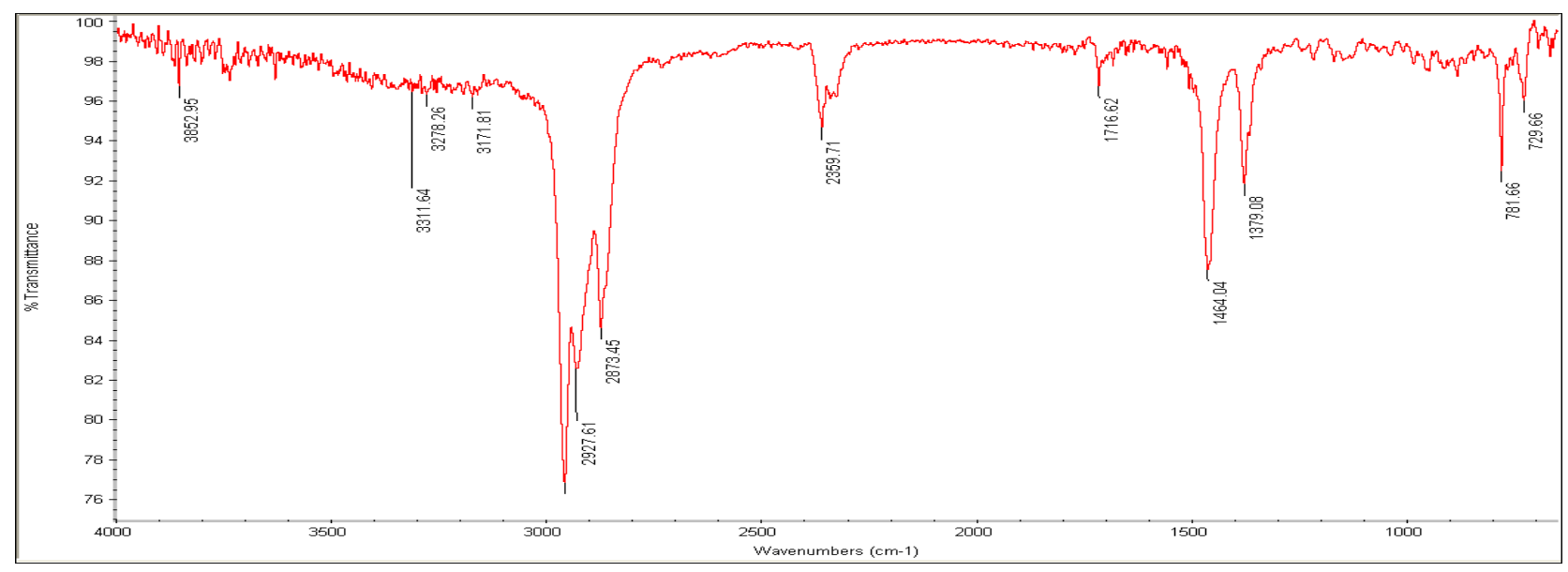


Fig.5 (c) FT-IR spectra of naphthalene treated with Staphylococcus pasteuri RD2

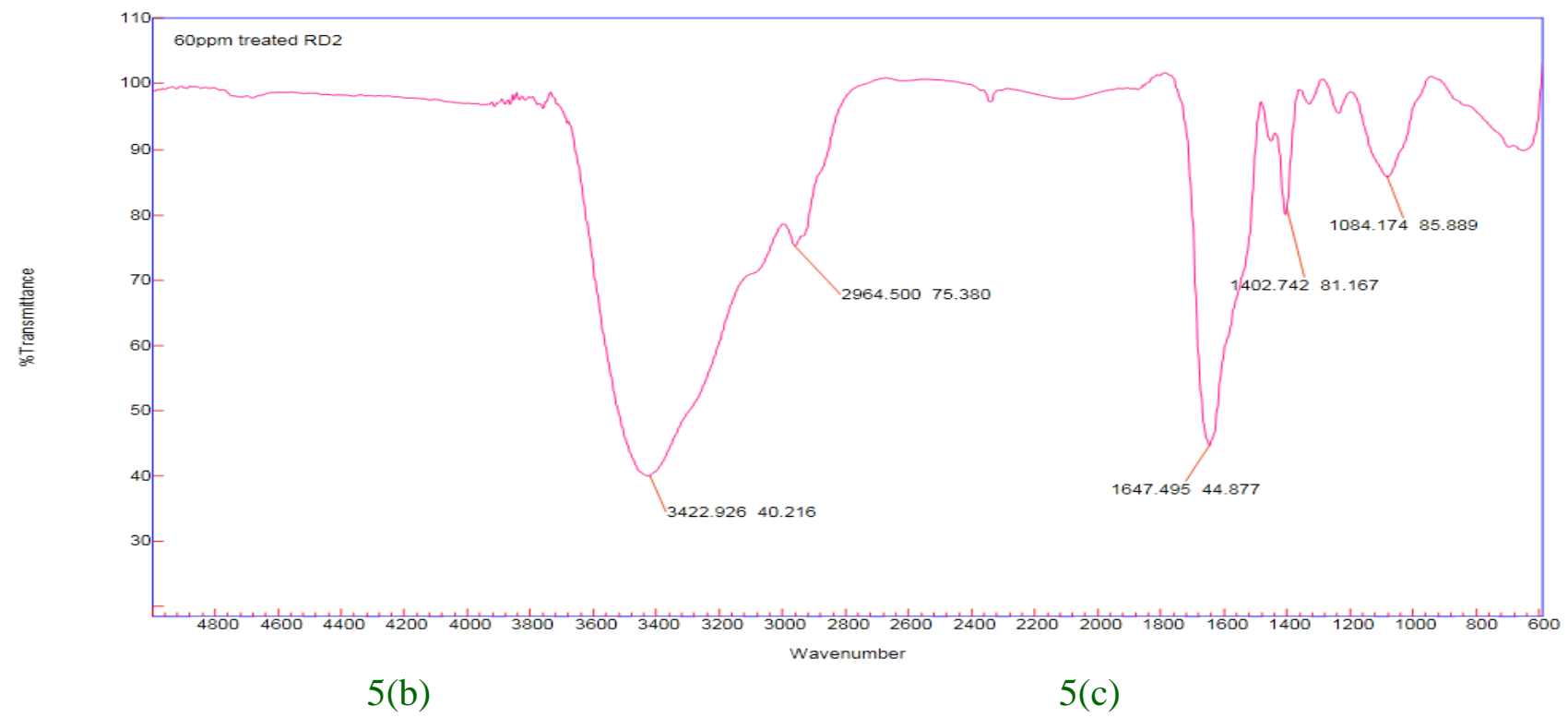

Fig.6 GC-MS of naphthalene degradation by Staphylococcus pasteuri RD2

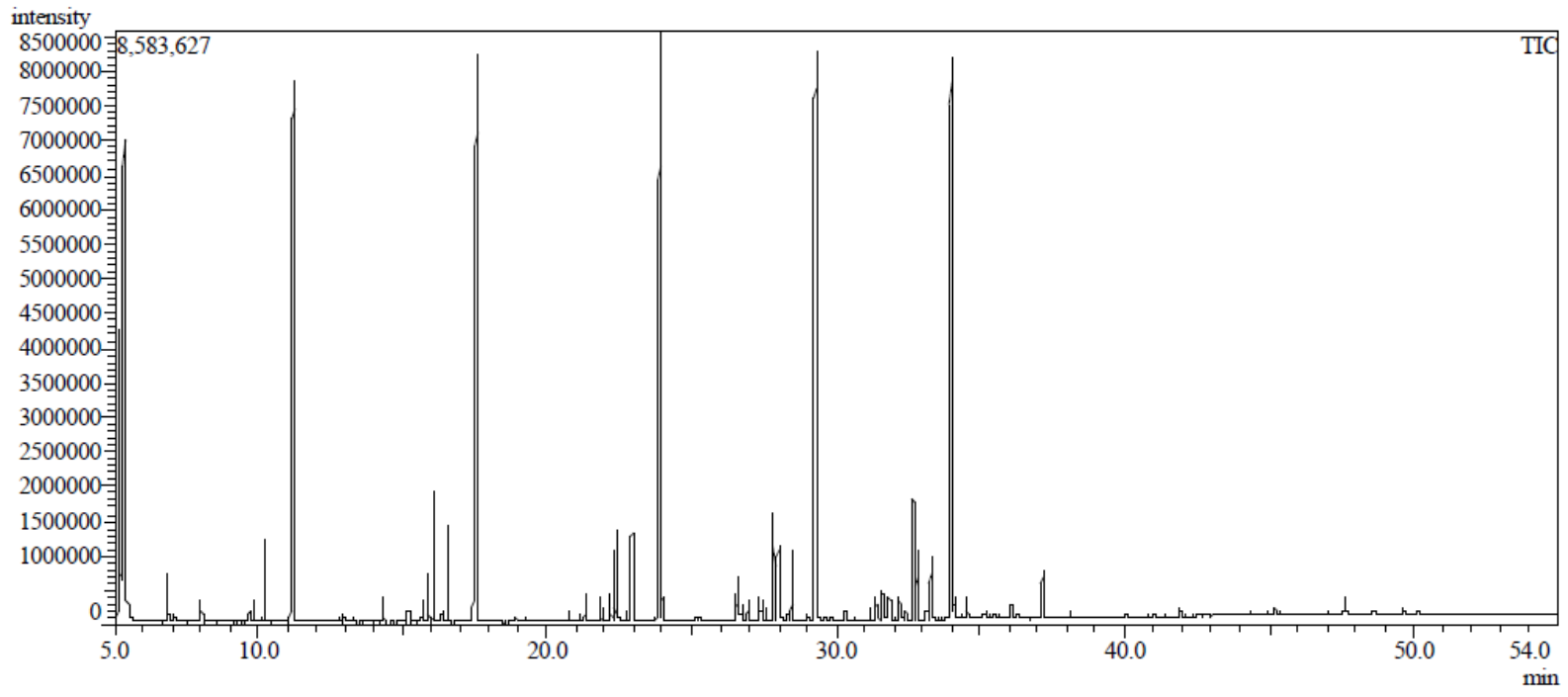

Degradation of naphthalene by hour indicated the metabolism of naphthalene Staphylococcus pasteuri strain in the culture broth by the bacterial strain (Fig. 4b). Thus there is a correlation between By utilizing naphthalene as the sole source of the cell growth and breakdown of naphthalene. The FT-IR spectra of the control, $60 \mathrm{ppm}$ Naphthalene taken in ATR mode (Fig. 5a) show peaks at 3311, 3278, 2927, 2873, 1716, 1464 and $1379 \mathrm{~cm}^{-1}$ which corresponds to N-H stretch, O-H stretch, C-H stretch, $\mathrm{C}=\mathrm{O}$ stretch, $\mathrm{C}=\mathrm{C}$ stretch and $\mathrm{CH}_{3}$ bending. The results of FT-IR spectra of hexane extract of culture broth supplemented 
with 40ppm naphthalene (Fig. 5b) exhibited characteristic peaks at 3450 and $2921 \mathrm{~cm}^{-1}$ indicating free O-H stretch, peak at $1647 \mathrm{~cm}^{-1}$ suggesting $\mathrm{NH}_{2}$ bending vibration and peaks at 1402, 1056 showing $\mathrm{CH}_{3}, \mathrm{CH}_{2}$ bending deformation and C-N stretching. Similarly, 60 ppm naphthalene culture broth (Fig. 5c) also showed characteristic peaks of free $\mathrm{O}-\mathrm{H}$ stretch and $\mathrm{CH}_{2}, \mathrm{CH}$ strong vibrations, $\mathrm{NH}_{2}$ bending vibration, $\mathrm{CH}_{3}, \mathrm{CH}_{2}$ bending deformation and $\mathrm{C}-\mathrm{N}$ stretch around 3422, 2964, 1647, 1402 and $1084 \mathrm{~cm}^{-1}$ respectively. The absence of such peaks at these regions in the control after treatment indicates the degradation of naphthalene by Staphylococcus pasteuri.

Annweiler et al., (2000) reported 2carboxycinnamic acid, phthalic acid and benzoic acid as transformation products of naphthalene. They concluded phthalic acid as second transformation product of naphthalene with 2-carboxy functionality, arise from degradation of 2-carboxycinnamic acid, that arise through ortho-type cleavage of 1,2dihydroxy naphthalene or meta-type of 2,3dihydroxy naphthalene. In our study we have not detected 2-carboxycinnamic acid and benzoic acid but detected phthalic acid (RT 35.15 min.), may arise from further degradation of 2-carboxycinnamic acid. 2carboxycinnamic acid was not detected in our study, probably it has been instantly transformed to phthalic acid before extraction (Doleyet al., 2017). R.U. Meckenstock et al., (2004) detected 2-carboxycyclohexylacetic acid that was probably generated by cleavage of a $\mathrm{C}_{2}$-fragment via beta-oxidation of other metabolite, a $\mathrm{C}_{11} \mathrm{H}_{16} \mathrm{O}_{4}$-diacid. They reported that naphthalene, methyl naphthalene and tetraline degraded via a novel central degradation pathway with cyclohexanoic compounds as intermediate. In our study we have detected 1-Cyclohexane-1-Carboxylic acid (RT $23.35 \mathrm{~min}$ ) as ring cleavage product along with acetic acid (RT $19.35 \mathrm{~min}$ ), propanoic acid (RT 30.26) and oxalic acid
(RT $30.26 \mathrm{~min}$ ) as other metabolites of naphthalene. The enzyme system of microorganisms convert the aromatic compounds in to ortho or paradihydroxy phenol derivatives, followed by cleavage of the ring to aliphatic acids. However, a large number of microorganisms able to modify aromatic compound either by hydroxylation or elimination of substituent groups without causing ring fission (Evans 1963). Benzoate, salicylate etc are the common intermediates in degradative pathways of more complex aromatic compounds. These acids are converted to catechol by bacterial oxidases enzyme before ring fission. Ethylhexyl salicylate (RT 30.09 min.) and 1,2Cyclohexanedicarboxyldehyde (RT 20.99 min.) are the another naphthalene degradative products detected in our study, reveals that the bacterial strain Staphylococcus pasteuri RB2 efficiently degrade naphthalene to its derivatives.

\section{Acknowledgement}

Authors are grateful to University Grant Commission for financial support to the corresponding author to carry out this research work. Authors are also highly thankful to IITG, IASST, Guwahati for providing SEM and GC-MS facilities. Sincere thanks also to Biotech Hub., and Department of Chemistry, B. Borooah College for technical support to perform DNA isolation and FTIR facility respectively.

\section{References}

Annweiler, E, Richnow, H.H, Antranikian, G., Hebenbrock, S., Garms, C., Franke, S, Francke, W., and Michaelis, W. 2000. Naphthalene degradation and incorporation of 566: 518-532.

Annweiler, E.,Materna, A.,Safinowski, M., Kappler, A., Richnow, H.H., Michaelis, W., and Meckenstock, R.U. (2000). Anaerobic degradation of 2-methyl naphthalene by a 
sulfate-reducing enrichment culture. Appl. Environ. Microbiol. 66, 5329-5333.

Annweiler, E., Michaelis, W., Meckenstock, R.U. Identical ring cleavage products during anaerobic degradation of naphthalene, 2methylnaphthalene, and tetralin indicate a new metabolic pathway. Appl. Environ. Microbiol. 2002, 68, 852-858.

Bergeys Manual of Systematic Bacteriology.1984, 86, 89a and b. 1-4, Holt JG, (Ed.In chief). Williams and Wilkins, Baltimore.

Cappuccino JG and Sherman N. 2005. Microbiology: A Laboratory Manual. $7^{\text {th }}$ Edition

Chen Lin., Li Gan andZu-Liang Chen. 2010. Biodegradation of naphthalene by strain Bacillus fusiformis (BFN). Journal of Hazardous Materials 182: 771-777.

Doley, R., Barthakur, M. and Goswami. B. S. 2017. Microbial Degradation of Aromatic Hydrocarbon: Naphthalene through Nocardiopsisalba RD3. Int.J.Curr. Microbiol.App.Sci. 6(7): 1174-1181

Kafilzadeh, F., Rafiee S. and Tahery, Y. 2011. Evaluation of Bioremediation of naphthalene using native bacteria isolated from oil contaminated soils in Iran. Annals of Biological Research. 2: 610-616.

Mallick S., Chatterjee S. and Dutta T.K. 2007. A novel degradation pathway in the assimilation of phenanthrene by Staphylococcus sp. strain PN/Y via metacleavage of 2-hydroxy-1-naphthoic acid: formation of trans-2,3-dioxo-5-(29 hydroxyphenyl)-pent-4-enoic acid. Microbiology. 153, 2104-2115.

Mittal, A. and Singh, A. 2009. Isolation of Hydrocarbon degrading Bacteria from soil contaminated with crude oil spills. Indian Journal of Experimental Biology. 47: 760765.

Mrozik, A., Priotowska-Seget, Z. and Labuzek, S.
2003. Bacterial degradation and bioremediation of Polycyclic aromatic Hydrocarbon (2003). Polish J. of Environ. Studies.12: 15.

Othman. N. Hussain. N. and Abdul Talib.S. 2010. Degradation of polycyclic aromatic hydrocarbon by pure strain isolated from Municipal sludge: Synergistic and Cometabolism Phenomena. International conference on Environment.

Pawar, A.N., Ugale S.S., More M.G., Kokani, N.F. and Khandelwal, S.R. 2013. Biological Degradation of Naphthalene: A New Era. J.Bioremed.Biodeg. 4:203.

Prajapati, B., Shiv, G., Gaherwal, S., Billore, K., and Soni, R. 2016. Isolation and Identification of Naphthalene Degrading Microbe from Petroleum Contaminated Soil. International Journal of Research in Chemistry and Environment. 6(4): 26-29.

Singh A. and Ward O.P. (Eds.). 2004. "Biodegradation and Bioremediation", Springer-Verlag Berlin Heidelberg. pp. 174.

U.S. Environmental Protection Agency (1977). Serial no. 95-12.U.S. Government Printing Office, Washington, D.C.

Ward OP., Singh A. and Van, H. J. 2003. Accelerated biodegradation of petroleum hydrocarbon waste. J Industrial Microbial Biotechnol. 30: 260-270.

Zhang X., Young L.Y. Carboxylation as an initial reaction in the anaerobic metabolism of naphthalene and phenanthrene by sulfidogenic consortia. Appl. Environ. Microbiol.1997,

Zhang X., Young L.Y. Carboxylation as an initial reaction in the anaerobic metabolism of naphthalene and phenanthrene by sulfidogenic consortia. Appl. Environ. Microbiol. 1997.

\section{How to cite this article:}

Ruby Doley and Manoj Barthakur. 2017. Biodegradation of Naphthalene by Staphylococcus pasteuri RD2 Isolated from Oil Contaminated Soil. Int.J.Curr.Microbiol.App.Sci. 6(12): 13101319. doi: https://doi.org/10.20546/ijcmas.2017.612.148 